International Symposium for Next Generation Infrastructure

October 1-4, 2013, Wollongong, Australia

\title{
The Care Of Victims: Implications of the Productivity Commission's Proposed No Fault Insurance Scheme
}

\begin{abstract}
Harrison $\mathrm{M}^{\mathrm{a}}$
Abstract: Traffic accidents impose large costs, with 1,291 road deaths in Australia in 2011. The total costs of road accidents were estimated to be $\$ 17$ billion in 2003, equivalent to 2.3 per cent of that year's GDP, averaging around 8.4 cents per vehicle kilometre. The Productivity Commission has recommended replacing tort law with a compulsory, government run first party insurance scheme, where all victims receive compensation from the state, regardless of fault. The proposal is being implemented across Australia, NSW has adopted it this year. Contrary to the PC's assertions, the evidence is that no fault insurance would increase traffic fatalities by 10-30 per cent and accidents by even more. This has implications for the safety design of road infrastructure. An inter-disciplinary approach is taken, in this paper, combining, law, economics and transportation engineering to examine the interaction of legal rules, insurance arrangements, economic incentives and physical infrastructure.
\end{abstract}

Key words: No-fault insurance; Tort law; Third party insurance; Optimal precautions; Activity level; Accident costs

\section{Introduction}

In its 2011 "Disability Care and Support" report, the Productivity Commission recommended replacing the current State based disability support schemes with a National Disability Insurance Scheme (NDIS). With attention focused on this plan for multi-billion dollar increases in spending on disability support, and its financing, receiving less scrutiny is the other recommendation in the Productivity Commission's report, that:

State and territory governments should create insurance schemes that would provide fullyfunded care and support for all catastrophic injuries on a no-fault basis, and that would collectively constitute a National Injury Insurance Scheme (NIIS).

The NIIS would include all medical treatment, rehabilitation, home and vehicle modifications and care costs, and cover catastrophic injuries from motor vehicle, medical (excluding cases of cerebral palsy associated with pregnancy or birth, which would be covered by the NDIS), criminal and general accidents. Common law rights to sue for long-term care and support should be removed, though access to damages for pecuniary and economic loss, and general damages would remain. ${ }^{1}$

The Productivity Commission recommended all states create no-fault motor accident insurance schemes by 2013 and other forms of catastrophic injury be covered by 2015 and an inquiry be held in 2020 to examine widening coverage to damage for pecuniary and economic loss and to some non-catastrophic injuries. ${ }^{1}$

\footnotetext{
${ }^{a}$ SMART Infrastructure Facility, University of Wollongong, Australia
} http://dx.doi.org/10.14453/isngi2013.proc.21 
Currently the Northern Territory, NSW, Victoria and Tasmania have no fault insurance schemes for motor vehicle accidents, the other states have fault based tort law liability, where an accident victim can only claim from a negligent injurer (who usually carries compulsory third party insurance). ${ }^{1}$ The Productivity Commission's NIIS proposal involves major changes for all. Except for the Northern Territory (which abolished common law rights to sue for transport accidents), the current no fault schemes are 'add-ons', with limited no-fault benefits. They preserve the right to sue for damages under tort law and apply only to motor vehicle accidents. Some require a threshold level of damage to sue under common law; others do not restrict access to tort actions. ${ }^{2}$

The States have agreed to introduce no-fault lifetime care and support for people who are catastrophically injured in motor vehicle accidents prior to the commencement of the NDIS launch. ${ }^{3}$ NSW and South Australia have announced plans to convert their compulsory third party car insurance arrangements, where drivers must insure against the risk of being held legally liable to another (the 'third party'), into no-fault schemes - where the driver and all victims claim from the scheme regardless of fault. It includes, therefore, compulsory first party insurance, where the policy holder (the first party) is insured against the risk of suffering loss. The Productivity Commission estimates the NIIS would have cost an extra $\$ 830$ million a year in 2011- to be raised from increasing compulsory third party insurance premiums for motor vehicles, medical indemnity premiums, surcharges on rail passengers, levies on boats, increased municipal rates and from general revenue. ${ }^{1}$ The Productivity Commission's proposal replaces legal liability with a compulsory, government run first party insurance scheme. The Productivity Commission asserts:

Nor is there evidence that the common law right to sue for compensation for care costs increases incentives for prudent behaviour by drivers, doctors and other parties."

This statement ignores and contradicts the vast theoretical and empirical law and economics literature on the very issues examined in the Commission's report: the effect of tort law and different liability arrangements, insurance, litigation costs, settlement, and no-fault insurance schemes. The Commission's proposal runs the risk of a large increase in accident costs, which can involve substantial negative externalities. A negative externality is an uncompensated net cost imposed by one agent on another without permission. If some of an action's costs are born by other people, then it may be taken even if the social costs are greater than the benefits. As a result external costs may be incurred even if they are not worth incurring. The economic analysis of how tort liability controls harmful externalities is one of the great accomplishments of law and economics. It has moved the central focus of tort law towards how best to induce strangers to take account of the full social costs of their actions and undertake optimal precautions (see Shavell ${ }^{4}$; and Landes and Foster ${ }^{5}$ ).

\section{The Law and Economics Analysis of Accidents}

The economic analysis of accidents starts with the observation that they are not entirely accidental. People do not choose to have accidents, but they can take precautions to reduce the probability and severity of accidents. For example, a motorist chooses what kind of car to drive, 
how often and what speed to drive it, how often to have its brakes checked, how much to drink before driving and so on. These decisions and many more, affect the cost the motorist imposes on other people.

The law and economics approach further observes that accidents are jointly determined by the actions of all parties involved. The problem is not just to control the injurer's behavior, the victim's actions also affect the probability and magnitude of harm. That is, it uses the model of bilateral precaution. Harm from accidents is probabilistic - whether an accident will occur is uncertain, and the probability of an accident occurring depends on the care or precautions taken by all parties involved. For example, let $\mathrm{L}$ be expected accident losses (for the moment, think of it as being per kilometer and the number of kilometers driven or walked is fixed). The injurer can take a level of care $X$ at a constant marginal cost of $C_{I}$ per unit and the victim can take a level of care $\mathrm{Y}$ at $\mathrm{C}_{\mathrm{V}}$ per unit.

Then $\mathrm{L}=\mathrm{L}(\mathrm{X}, \mathrm{Y}), \partial \mathrm{L} / \partial \mathrm{X}<0, \partial \mathrm{L} / \partial \mathrm{Y}<0, \partial^{2} \mathrm{~L} / \partial \mathrm{X}^{2}>0, \partial^{2} \mathrm{~L} / \partial \mathrm{Y}^{2}>0$. It will be assumed that $\partial^{2} \mathrm{~L} / \partial \mathrm{X} \partial \mathrm{Y}>0$ ( $\mathrm{X}$ and $\mathrm{Y}$ are substitutes). The efficient outcome minimises the total social costs of accidents: the costs of prevention, the costs of injuries that nonetheless occur, the costs of administration (such as litigation costs) and the costs of risk bearing. To achieve efficiency, parties should take all cost justified precautions - those precautions that save more in accident losses than the precaution costs. Ignoring litigation and risk bearing costs for now, the efficient outcome minimizes

$$
\mathrm{W}_{\mathrm{X}} \mathrm{X}+\mathrm{W}_{\mathrm{Y}} \mathrm{Y}+\mathrm{L}(\mathrm{X}, \mathrm{Y})
$$

At the efficient levels of care $\mathrm{X}^{*}, \mathrm{Y}^{*}$ the necessary first order conditions are

$$
\mathrm{W}_{\mathrm{X}}=-\partial \mathrm{L}\left(\mathrm{X}^{*}, \mathrm{Y}^{*}\right) / \partial \mathrm{X} ; \mathrm{W}_{\mathrm{Y}}=-\partial \mathrm{L}\left(\mathrm{X}^{*}, \mathrm{Y}^{*}\right) / \partial \mathrm{Y}=0 .^{\mathrm{b}}
$$

It is natural to ask: what set of legal rules will lead the parties to make efficient decisions. It is a complex problem. As the first order conditions show, the optimal level of care by each party depends on the care taken by the other party, and the decisions are taken independently and in advance of the parties' interaction. A decision maker has the incentive to make efficient decisions when faced with the full social cost of his actions, including the cost imposed on others. Then he would undertake actions only if their benefits exceed the social cost. In the jargon, to achieve efficiency we need to internalise the externalities.

\section{The Role of Tort Law}

Australia is a common law country, inheriting the body of judge made law built up in England over the centuries. The common law is by far the dominant source of the legal rules that govern the interactions between citizens. Victims enforce the common law and it creates incentives through injurers having to compensate their victims. Tort law deals with externalities between strangers - interactions outside a contractual relationship. A tort is a civil wrong: where one party inflicts damage on another, other than from breach of contract. Contract law deals with breaches of contract, which raises different issues - as the parties can negotiate before the accident and adjust the contract price - and is relevant for medical malpractice and workplace accidents.

\footnotetext{
${ }^{b}$ The above assumptions about the derivatives of the $\mathrm{L}(\mathrm{X}, \mathrm{Y})$ function ensure the second-order conditions are met.
} 
One way of inducing people to take appropriate precautions is to make them liable for the cost of the damage they do to others if they don't - by allowing their victims to sue them for damages. That is, tort damages are a way of forcing people to take account of the costs they impose on others. If a party imposes costs on someone else, is sued and held liable - then he must make the victim 'whole'. That is, pay the victim damages, a sum of money that compensates for the damage imposed, transferring the cost back to the person responsible internalizing the externality to bring private costs in line with social costs.

The main basis for liability for damage from accidents is the tort of negligence. Developed in the nineteenth century, it became important after the invention of the railway, and later the motor car. It imposes a duty to take reasonable care to avoid acts or omissions which you can reasonably foresee would be likely to injure another. Victims must also behave reasonably and take reasonable care - or they will be held to have contributed to the accident and be guilty of contributory negligence. Under the common law, contributory negligence was a defense - the defendant was not liable if the plaintiff was contributorily negligent. In Australia, statute has modified the common law so that a negligent injurer is only partially liable if the victim is also negligent. Contributory negligence reduces the damages paid by the proportion the defendants conduct contributed to the accident - what economists call comparative negligence. For example, if the plaintiff is considered 40 per cent responsible for the accident, damages are reduced by 40 per cent.

\section{How the Rule of Negligence Can Result In Optimal Outcomes}

If the courts set the required standard of due care for each party at the efficient level, the efficient outcome can result. The courts look at the conduct of the defendant and the claimant relative to the norm of the 'reasonable person' to determine whether the defendant should bear the loss, which in practice requires judges to compare the cost of a precaution against its benefit. A reasonable person is obliged to take precautions that are cheap and eliminate a substantial risk, but not expensive precautions against a remote risk. Further, the adversarial nature of common law adjudication encourages the courts to think in terms of incremental changes, focusing on the behavior of the parties. Each party tries to persuade the judge the other party did not act with reasonable care by setting out actions the other party could have taken to avoid the accident. The party accused of negligence counters with reasons why this would not have reduced the likelihood of harm or would have been impractical, too expensive and unreasonable. The court process encourages courts to require only cost justified precautions.

The prospect of being found negligent gives all parties a strong incentive to reach the standard of due care. The following simple model shows how tort can solve the bilateral care problem and result in efficient outcomes. As each party's action affects the results of other parties' actions, and each makes their decision independently, game theory is the obvious way to model the effects of the law. Consider an accident between an injurer and a victim. Assume:

- Unilateral damage - only the victim suffers damage (think of a car running down a pedestrian).

- Risk neutrality. 
- Two levels of care: due care (not liable) or no care (negligent and liable).

- Damages fully compensate victims for their injuries.

- No mistakes. Courts set due care at the efficient level, observe actual care taken and each party knows the required care.

- Fixed number of trips by each party.

Each of these assumptions will be relaxed later in the paper. The payoffs from the care decisions each party must make are set out in the non-cooperative game between two parties summarized in Table 1 (player 1's payoffs are first in each cell). The individual strategies are investment of resources in preventing accidents. Expected accident costs (higher is worse) are L $(i, j)$ where $i$ is the motorists action and $\mathrm{j}$ is the pedestrian's action. The cost of taking care for the injurer and victim is $\mathrm{C}_{\mathrm{I}}$ and $\mathrm{C}_{\mathrm{V}}$. Lack of care increases expected accident costs: $\mathrm{L}(\mathrm{D}, \mathrm{D})<$ $\mathrm{L}(\mathrm{D}, \mathrm{N}), \mathrm{L}(\mathrm{N}, \mathrm{D})<\mathrm{L}(\mathrm{N}, \mathrm{N})$. If due care levels are set efficiently, the due level of care reduces accident costs by more than the costs of the care (total accident costs fall when take due care) and so: $\mathrm{C}_{\mathrm{V}}+\mathrm{L}(\mathrm{D}, \mathrm{D})<\mathrm{L}(\mathrm{D}, \mathrm{N}), \mathrm{C}_{\mathrm{I}}+\mathrm{L}(\mathrm{D}, \mathrm{D})<\mathrm{L}(\mathrm{N}, \mathrm{D}), \mathrm{C}_{\mathrm{I}}+\mathrm{L}(\mathrm{D}, \mathrm{N})<\mathrm{L}(\mathrm{N}, \mathrm{N})$ and $\mathrm{C}_{\mathrm{V}}+\mathrm{L}(\mathrm{N}$, $\mathrm{D})<\mathrm{L}(\mathrm{N}, \mathrm{N})$. Combining these gives $\mathrm{C}_{\mathrm{I}}+\mathrm{C}_{\mathrm{V}}+\mathrm{L}(\mathrm{D}, \mathrm{D})<\mathrm{L}(\mathrm{N}, \mathrm{N})$.

Table 1. Negligence game.

\begin{tabular}{|l|l|l|l|}
\hline \multirow{2}{*}{$\begin{array}{l}\text { Player 1: } \\
\text { Motorist (injurer) }\end{array}$} & Due care & $\mathrm{C}_{\mathrm{I}}$ & $\mathrm{C}_{\mathrm{I}}$ \\
& & $\mathrm{L}(\mathrm{D}, \mathrm{N})$ & $\mathrm{C}_{\mathrm{V}}+\mathrm{L}(\mathbf{D}, \mathbf{D})$ \\
\cline { 2 - 4 } & No care & $(1-\mathrm{b}) \mathrm{L}(\mathrm{N}, \mathrm{N})$ & $\mathrm{L}(\mathrm{N}, \mathrm{D})$ \\
$\mathrm{bL}(\mathrm{N}, \mathrm{N})$ & & \\
\hline & & & \\
\hline & & No care & Due care \\
\hline & & & \\
\hline & & Player 2: Pedestrian (victim) \\
\hline
\end{tabular}

The motorist is liable if he is negligent. If both the motorist and pedestrian are negligent, the pedestrian bears a portion $b$ of costs, and the motorist $(1-b)$. $b$ depends on the legal rule in force. Under pure negligence, the injurer is always liable if negligent and $b=0$. The traditional common law rule where contributory negligence is a defense, $b=1$. Under comparative negligence, $b$ is the share of the victims blame for the accident. Each party chooses the action that maximizes his benefits net of expected liability. As due care is set at the efficient level, a party that expects the other to take due care will take due care. If the pedestrian takes due care and the motorist does not, the motorist will be found negligent and bear all the accident costs. He has a big incentive to take due care and avoid these costs. If the motorist is expected to take due care, the victim bears all the accident costs and has an incentive to minimize them and take all cost justified precautions. 
If $\mathrm{C}_{\mathrm{I}}<(1-\mathrm{b}) \mathrm{L}(\mathrm{N}, \mathrm{N})$ the motorist has a dominant strategy to take care and the Nash equilibrium outcome is D,D the social optimum where both parties take the efficient level of care. The motorist always takes care, and that induces the pedestrian to take the efficient level of care. For example, this would occur under pure negligence, where $b=0$. The incentive not to be found negligent and liable gives the injurer an incentive to meet the court determined standard of due care. If the injurer takes due care, the accident costs are borne by the victim, who then has the incentive to take an efficient level of care.

If $\mathrm{C}_{\mathrm{V}}<\mathrm{bL}(\mathrm{N}, \mathrm{N})$ then the pedestrian has the dominant strategy to take care and the outcome is $\mathrm{D}, \mathrm{D}$. For example, this would occur when comparative negligence is a defense.

At least one of those outcomes must be true as:

$$
\mathrm{C}_{\mathrm{I}}+\mathrm{C}_{\mathrm{V}}+\mathrm{L}(\mathrm{D}, \mathrm{D})<\mathrm{L}(\mathrm{N}, \mathrm{N})=(1-\mathrm{b}) \mathrm{L}(\mathrm{N}, \mathrm{N})+\mathrm{bL}(\mathrm{N}, \mathrm{N})
$$

So, at least one party has the dominant strategy to take care. The other party expects this and so will take the efficient level of care. Each party has the duty to behave reasonably, but also the right to act on the presumption that others are behaving reasonably. The tort of negligence gives double responsibility at the margin. When the other takes care, each party faces the full social cost of harm up to the required standard of care. The analysis generalises to continuous, rather than two levels, of care. If due care is set at the efficient level, the efficient outcome results.

\section{The Role Of Insurance}

Analyzing the effect of insurance requires us to drop the assumption of risk aversion, so that there is a cost to bearing risk and a demand for insurance. For example, in the equilibrium in the simple model of negligence, there is no negligence and no damages paid - so the victims bear the remaining accident costs. That creates a demand for first party insurance. Tort law is bad at providing insurance and compensation, with poor coverage (it covers only a small sub-set of losses: where there is a negligent party to sue) and high legal costs. The accident problem involves not only the goal of appropriately reducing the risks of accidents but also allocating and spreading the risks of losses from accidents that do occur - protecting risk averse people against risk. Rrisk aversion increases the incentive to meet the standard and can lead to excessive care in the absence of insurance (when care is continuous).

The first best outcome would be for all parties to take the efficient amount of care and for risks to be fully insured and spread; but if an insurance policy completely eliminates risk, it may have an undesirable side effect. It removes the incentive for the insured to take care to reduce the risk of the accident occurring, the so-called moral hazard problem.

If the insurance company can observe the care taken, it can overcome the moral hazard problem by adjusting the premium to reflect the increase in the expected loss resulting from the insured person's taking less care. When care is not observable by the insurance company, insurance is imperfect and the individual cannot reduce his premium by taking more care, reducing the incentive to take care. If there is moral hazard, the insured takes no care and the probability of the accident increases - this raises the premium. In equilibrium the insurance policy must break even on the care chosen when it is accepted. This may result in the person not 
insuring at all - if the moral hazard effect of increased premiums outweighs the risk spreading benefits.

What is usually done is to provide partial insurance coverage, such as co-insurance or deductibles or premium increases after claims, in order to induce the insured person to take some precautions - trading off increased care against increased risk bearing. Often governments regulate to prevent insurance companies from doing so. For example, compulsory third party insurance in Australia tends to be uniform with no risk rating or use of co-insurance and deductibles.

\section{The Effect of No-Fault Insurance}

The effect of no-fault insurance is illustrated with the game in Table 2. It keeps the assumptions listed above (such as full insurance), except for risk neutrality. The motorist pays the same premium $\mathrm{P}$ whether he takes care or not, so has no incentive to take costly care. The pedestrian is fully compensated whether he takes care or not, and so has no incentive to take care. All parties have a dominant strategy not to take care. The Nash equilibrium is that neither party takes care, the worst outcome. Accident costs are higher when no-one takes care $(\mathrm{L}(\mathrm{N}, \mathrm{N})$ $>\mathrm{L}(\mathrm{D}, \mathrm{D}))$ the premium reflects the crash costs when no-one takes care, L $(\mathrm{N}, \mathrm{N})$. Compared with the outcome in Table 1, drivers are worse off (they now pay a premium that reflects high accident costs) and pedestrians better off (they are now fully insured).

Table 2. No-fault insurance.

\begin{tabular}{|l|l|l|l|}
\hline Player 1: & Due care & $\mathrm{C}_{\mathrm{I}}+\mathrm{P}$ & $\mathrm{C}_{\mathrm{I}}+\mathrm{P}$ \\
& & 0 & $\mathrm{C}_{\mathrm{V}}$ \\
\cline { 2 - 4 } & Notorist (injurer) & $\mathrm{P}$ & $\mathrm{P}$ \\
\hline & & 0 & $\mathrm{C}_{\mathrm{V}}$ \\
\hline & & No care & Due care \\
\hline & & Player 2: Pedestrian (victim) \\
\hline
\end{tabular}

There is a trade-off between increased accident costs and better compensation and risk spreading. But pedestrians always had the option of taking out first party insurance. If they chose not to because the moral hazard effect increased premiums too much, then it is inefficient to compel their insurance. 


\section{Compulsory Third Party Insurance}

In the simple model of Table 1, there is no demand for third party liability insurance because motorists have the incentive to take care; they are not negligent, and not liable. Drivers may be found negligent because of mistakes - they may actually be negligent because they make mistakes in the level of care taken (such as a lapse in concentration) or courts may make errors in assessing the actual care taken and wrongly find an injurer negligent, or the driver may gamble on the court thinking he was not negligent when he really was, and lose.

If care is continuous, court errors tend to encourage parties to take more care, greater than the optimal level, especially if they are risk averse. The higher the level of precautions taken, the smaller the chance of being wrongly found negligent. Risk-bearing is relevant for two reasons: not only because potential victims may face the risk of accident losses, but also because potential injurers may face the risk of liability. The chance of being found liable because of errors by the court or own mistakes creates a demand for third party insurance. Voluntary third party insurance tends to be efficient, even if it is imperfect and reduces care.

There is a trade-off between risk spreading and care - greater risk spreading reduces incentives for care and increases accident costs. But if victims are fully compensated, that cost is internalised in the price of the insurance, which reflects care taken under the policy, and third parties are fully compensated for increase in accidents. Insurance is a voluntary transaction and so it will take place only if both parties believe the gain balances the loss. If individuals choose to purchase insurance, they reveal that the risk spreading benefits outweigh the extra accident costs. If victims are not fully compensated, then they bear some of the extra accident costs and it cannot be guaranteed liability insurance is desirable. Further, if liability insurance is compulsory (as it is in Australia), it cannot be guaranteed that the risk spreading benefits outweigh the extra accident costs.

The Productivity Commission recognizes that no-fault insurance reduces incentives to take care, but it claims that:

in the presence of insurance, especially with little focus on risk-rating for some causes of injury, the common law does not provide incentives for prudent behavior by motorists and other parties. ${ }^{1}$

and that no-fault insurance would

currently perform no worse at deterring excessively risky behavior, as despite the appearance of the common law, it is the insurer that pays. ${ }^{1}$

That is, the Productivity Commission claims that current compulsory third party insurance removes any incentives for care, so that replacing the current system with no-fault insurance would not increase accidents. But the Productivity Commission ignores a fundamental contribution of the law and economics literature: the model of bilateral care and the importance 
of victim care. The chance of an accident depends on the actions of both the injurer and victim. Even if we assume full, imperfect compulsory third party insurance, with no risk rating or use of co-insurance and deductibles, and that moral hazard means the insured takes no care at all, tort law still affects the victim's incentive. If the injurer is negligent, the victim may claim compensation from the insurer of the owner/driver of the 'at-fault' vehicle. But if the victim is also at fault, the compensation may be reduced under comparative negligence, providing an incentive for the victim to meet the standard of due care set by the courts, in order to preserve his right to damages. Table 3 illustrates.

Table 3. Compulsory third party liability insurance.

\begin{tabular}{|c|c|c|c|}
\hline $\begin{array}{l}\text { Player 1: } \\
\text { Motorist (injurer) }\end{array}$ & Due care & $\begin{array}{l}\mathrm{C}_{\mathrm{I}}+\mathrm{P} \\
\mathrm{L}(\mathrm{D}, \mathrm{N})\end{array}$ & $\begin{array}{l}C_{I}+P \\
C_{V}+L(D, D)\end{array}$ \\
\hline & No care & $\begin{array}{l}P \\
b L(N, N)\end{array}$ & $\begin{array}{l}\mathrm{P} \\
\mathrm{C}_{\mathrm{V}}\end{array}$ \\
\hline & & No care & Due care \\
\hline & & \multicolumn{2}{|c|}{ Player 2: Pedestrian (victim) } \\
\hline
\end{tabular}

The motorist pays the premium $\mathrm{P}$ whether he takes care or not, and so has a dominant strategy to take no care. The pedestrian takes care if $\mathrm{C}_{\mathrm{V}}<\mathrm{bL}(\mathrm{N}, \mathrm{N})$. As the standard of care is set efficiently, $\mathrm{C}_{\mathrm{V}}+\mathrm{L}(\mathrm{N}, \mathrm{D})<\mathrm{L}(\mathrm{N}, \mathrm{N})$, and so the pedestrian may meet the standard and take care. If $\mathrm{b}=1$, as under the common law defence of contributory negligence, then the victim has an incentive to meet the standard of care. Given compulsory third party insurance, the movement from contributory to comparative negligence has a large potential cost, it may reduce victim care, moving the equilibrium from $\mathrm{N}, \mathrm{D}$ to $\mathrm{N}, \mathrm{N}$, increasing expected accident costs from $\mathrm{L}(\mathrm{N}, \mathrm{D})$ to $\mathrm{L}(\mathrm{N}, \mathrm{N})$. Moving to no-fault insurance removes the victim's incentive to take care, increasing accidents.

More generally, if care is continuous, the victim may have an incentive to take due care under compulsory third party insurance, but if not, he still has an incentive to take some care - more than under no-fault insurance. Victims' care is particularly important in motor vehicle accidents, where a substantial portion of accidents involve motor vehicles crashing into each other (bilateral damage). In 2010, multi-vehicle crashes were 42 per cent of Australian fatal road traffic accidents. ${ }^{6}$ Drivers cannot be sure in advance whether they will be an injurer or a victim. Even with compulsory third party insurance, tort law gives drivers an incentive to be careful in their role as victims - so their damages are not reduced through comparative negligence.

Dropping the assumption of unilateral damage means that tort law gives drivers an incentive to take care even with imperfect compulsory third party insurance. In fact, in the bilateral 
damage case, both drivers may have an incentive to meet the standard of due care and the optimal outcome is reached. Again, the common law rule of contributory negligence as a defence would ensure the worst $\mathrm{N}, \mathrm{N}$ outcome, where no-one takes care, is avoided - but it is a possibility under comparative negligence. More generally, some drivers may not have an incentive to meet the standard, but with continuous care they would take more care than under no fault insurance.

The Productivity Commission argues that no-fault insurance will not increase accidents because injurers with third party liability insurance currently have no incentive to take care. But it proposes to extend no-fault insurance to cover all general accidents, such as household accidents, even where injurers do have compulsory third party liability insurance, reducing incentives for injurer and victim care. Moreover, self-inflicted accidents would be covered such as falling off ladders or single vehicle accidents, which were 44 per cent of fatal road traffic accidents in Australia in $2010,{ }^{6}$ although some of the deaths are passengers. When no other person contributes to, or is involved in, the accident, the costs of these accidents tend to be internalised and efficient levels of accident prevention adopted (the victim and injurer are the same person). Furthermore, people can choose to take out first party insurance and internalize the resulting moral hazard costs. Introducing compulsory no fault insurance for general accidents, financed through municipal rates, will externalise costs to taxpayers, reducing the incentives for care.

\section{Dropping the Other Assumptions}

If courts do not calculate optimal care correctly they will set the standard above or below the efficient level. The parties may or may not meet the standard of due care. If they meet the standard, the tort system encourages them to take some care. If they do not meet the standard, they will be liable, will bear accident costs and have the incentive to take some care. In both cases, tort law gives more care than no fault insurance. Victims have a greater incentive to take care when damages only partially compensate them, so that they bear some accident costs. They are more likely to meet the due care standard (and perhaps even exceed it) and will take some care even under a no-fault scheme. But a no-fault scheme reduces the costs that negligent victims bear, and reduces the incentive to take care relative to tort law with compulsory third party insurance. Injurers have no incentive to take care under either.

A further law and economics insight that the Productivity Commission ignore is the incentive legal and insurance arrangements give for excessive activity levels. Only observable precautions can be made part of the court's standard of due care, and the prospect of being found negligent does not encourage parties to take cost-justified precautions that the court cannot observe. The activity level is extent of participation in the activity that is the source of the accident, such as kilometres driven. Usually courts do not include the activity level in the required standard of care, either because they cannot observe it or cannot judge whether is excessive. The court can judge whether the driver was negligent in how he drove but not whether he was negligent in how much he drove--whether his marginal trip was worth taking, given the expected accident costs it produced. 
Expected accident losses depend not only on the care exercised by each party but also on each party's activity level. For example, the number of car accidents depends on how many kilometres are driven. Under a negligence rule, drivers drive too much, since having taken the efficient level of precaution they are no longer liable for damages. Injurers do not bear the full social costs of their activity, but impose an external cost on accident victims, who bear their accident costs. Injurers only consider their net benefits from extra participation in the activity but not the increase in expected victim accident costs, resulting in excessive activity levels. Under compulsory third party insurance, accident costs that result from negligence are externalised onto the insurance company. But the premium charged to drivers will reflect this cost - internalising this cost for the participation decision (whether to drive at all), which may deter some from becoming drivers (such as young high risk drivers). But as insurance premiums are some fixed annual amount and do not vary with kilometres driven, if the driver chooses to participate, there is still an incentive for excessive activity levels (i.e. to drive too many kilometres), with accident costs externalised across premiums for all drivers. If damages under-compensate accident victims, then they bear some of the external cost as well.

The per kilometre accident externality is significant. Connelly and Supangan ${ }^{7}$ estimated the total costs of road traffic crashes in Australia as $\$ 17$ billion in 2003, equivalent to 2.3 per cent of that year's GDP. Motor vehicles in Australia travelled an estimated 201,497 million kilometres in the 12 months ended 31 October $2003,{ }^{8}$ so accident costs averaged around 8.4 cents per vehicle kilometre. No fault insurance exacerbates the activity level externality. It increases the accident externality per kilometre through reducing care and covers a greater portion of victim accident costs (externalising more accident costs) - both effects reducing the private cost per kilometre driven (and walked), increasing activity levels. The Productivity Commission do not consider this externality or policies to combat it, such as per kilometre insurance premiums.

\section{The Likely Effects of No Fault Insurance}

No-fault insurance will, therefore, increase accidents, even when replacing tort liability combined with imperfect, non-risk rated compulsory third party insurance. No fault insurance increases the accident rate per kilometre and kilometres driven, increasing external accident costs. The Productivity Commission point to the large litigation costs associated with tort law, but the litigation costs may be worth bearing if they cause enough efficient deterrence. The issue is which system is socially most efficient given overall costs and benefits, which include administrative and legal costs. The increase in accidents depends on the importance of victim's care and its response to changes in incentives. Exactly how much deterrence tort law provides and the extent to which replacing the negligence rule with no fault insurance will increase accident costs through reducing care and increasing activity levels is an empirical issue.

The literature finds tort liability provides a significant amount of deterrence, especially for automobile accidents (see, for example, the summaries in Schwartz ${ }^{9}$, Dewees et $\mathrm{al}^{10}$; van Velthoven $^{11}$; Sloan and Chepke ${ }^{12}$; and Liao and White ${ }^{13}$ ). Not the least is the evidence on nofault insurance. The studies on no fault insurance usually examine the effect of a shift to no-fault insurance on motor vehicle accident deaths, despite many no-fault schemes leaving tort liability intact in death cases. The justification is the probabilistic nature of accidents - less care means more accidents and some fraction will be fatal. ${ }^{14}$ The results differ greatly - some finding 
shifting to no-fault in various states in the U.S. had no effect, others finding a 15 per cent increase in deaths. That is to be expected, as the switch to no fault involves changes in liability rules and in insurance arrangements. The effect of introducing no-fault insurance depends on the system before it was introduced (such as liability insurance arrangements) and the details of the scheme introduced. For example, many schemes (as in NSW and Victoria) retain large elements of tort law and provide relatively modest no-liability benefits. For example, many no fault schemes exclude damages for pain and suffering, and so under-compensate victims (which increases victim care).

The most relevant studies for the NIIS proposal examine the effects of a shift to a pure no fault scheme that abolishes tort liability, as in New Zealand or for motor vehicles in Quebec and the Northern Territory. Swan and McEwin ${ }^{15,16}$ present empirical evidence on the switch to nofault in New Zealand and the Northern Territory, compared to other states of Australia and find it to be associated with a substantial increase of 16 to 20 percent in the number of road fatalities. In Quebec, fatalities increased 3 - 9 per cent (see for example, van Velthoven and Dewees et al). ${ }^{11}$ Hause finds little initial effect of the NZ scheme on overall fatality rates, but a modest long run trend effect in increasing fatal accident rates over what they otherwise would have been. ${ }^{17}$ Clearly there is a trade-off that the Productivity Commission ignores. No fault insurance may compensate victims better, but is likely to increase accident costs. It is a difficult policy issue what are the equity effects of helping those with catastrophic injuries, but creating more people in those circumstances? It doesn't help to assume the trade-off doesn't exist.

\section{Implications for Highway Expenditure}

The prospect of substantial increases in traffic accidents has implications for the safety design of road infrastructure, increasing the optimal amount of investment. If accident costs are $\mathrm{A}=\mathrm{A}$ $(\mathrm{H}, \mathrm{Z})$ where $\mathrm{Z}$ is dangerous driving (a fall in driver care and increase in kilometres driven increases $\mathrm{Z}$ ) and $\mathrm{H}$ is investment in road infrastructure, where $\partial \mathrm{A} / \partial \mathrm{H}=\mathrm{A}_{\mathrm{H}}<0$ and $\partial \mathrm{A} / \partial \mathrm{Z}=\mathrm{A}_{\mathrm{Z}}$ $>0$. If $H$ costs $W$ per unit, then if we choose $H$ to minimise $A(H, Z)+W H$ then the first-order condition for the optimal level of $\mathrm{H}$, which minimises accident plus infrastructure costs, is $A_{H}$ $(\mathrm{H}, \mathrm{Z})+\mathrm{W}=0$.

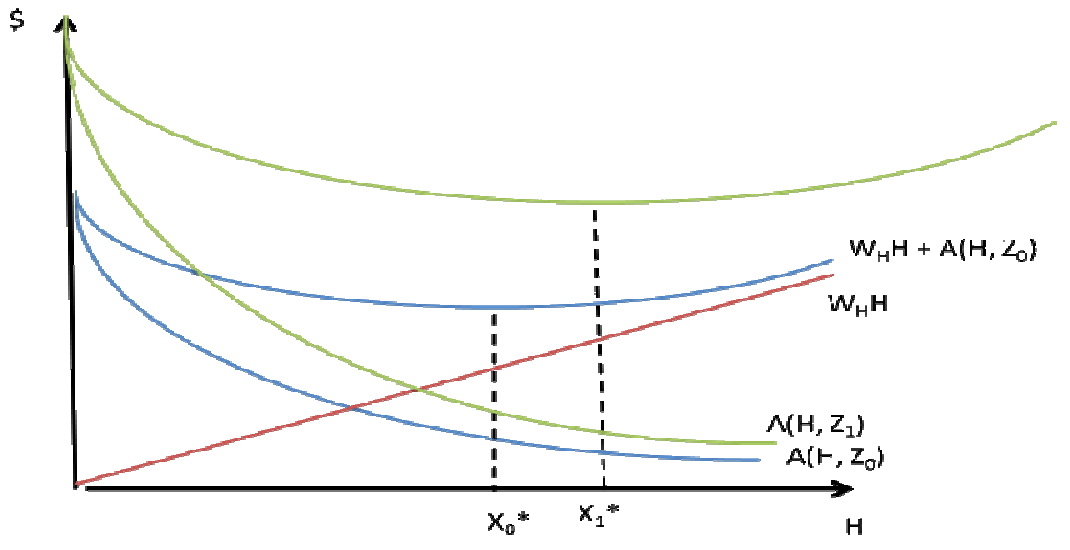

Figure 1. Optimal highway investment. 
The introduction of no-fault insurance would increase $\mathrm{Z}$. If $\mathrm{A}_{\mathrm{ZH}}<0$ then an increase in $\mathrm{Z}$ from the introduction of no fault insurance will make $A_{H}$ more negative and increase the optimal amount of $\mathrm{H}(\mathrm{H}$ and $\mathrm{Z}$ are substitutes). If $\mathrm{Z}$ is endogenous, then the rise in $\mathrm{H}$ will further increase $\mathrm{Z}$, which increases $\mathrm{H}$ further.

An increase in $\mathrm{Z}$ from $\mathrm{Z}_{0}$ to $\mathrm{Z}_{1}$ from the introduction of no-fault insurance shifts the $\mathrm{A}(\mathrm{H}, \mathrm{Z})$ curve up (from the blue to the green curves) and makes it steeper if $A_{Z H}<0$. This raises the optimal $\mathrm{H}$ from $\mathrm{X}_{0} *$ to $\mathrm{X}_{1}$ *.

\section{References}

${ }^{1}$ Productivity Commission, Disability Care and Support, Report no. 54, Canberra, 2011.

${ }^{2}$ Luntz, H., D., Hambly, K., Burns, J., Dietrich, J., and Foster, N., Torts Cases and Commentary, 6th edition, LexisNexis Butterworth, 2009.

${ }^{3}$ Council of Australian Governments (COAG), Intergovernmental Agreement for the National Disability Insurance Scheme (NDIS) Launch, Undated.

${ }^{4}$ Shavell, S., Economic Analysis of Accident Law, Harvard University Press, Cambridge, Massachusetts; London, England, 1987.

${ }^{5}$ Landes, W., and Posner, R., The Economic Structure of Tort Law Harvard University Press, Cambridge, Massachusetts; London, England, 1987.

${ }^{6}$ Australian Bureau of Statistics, "Accidents, injuries and fatalities", Year Book Australia, 2012, 1301.0, 2013.

${ }^{7}$ Connelly L., and Supangan, R., 'The economic costs of road traffic crashes: Australia, states and territories", Accident Analysis and Prevention, Vol. 38, No. 6, 2006, pp. 1087-93. http://dx.doi.org/10.1016/j.aap.2006.04.015

${ }^{8}$ Australian Bureau of Statistics (ABS), Survey of Motor Vehicle Use, Australia, 9208.0, October, 2003,

URL: http://www.abs.gov.au/AUSSTATS/abs@.nsf/ProductsbyReleaseDate/3EAAB384EF 8D2F62CA2570800072002D?OpenDocument

${ }^{9}$ Schwartz, G., "Reality in the Economic Analysis of Tort Law: Does Tort Law Really Deter?", 42 UCLA Law Review, Rev. 377, Dec, 1994.

${ }^{10}$ Dewees, D., Duff, D., and Trebilcock, M., Exploring the Domain of Accident Law: Taking the Facts Seriously, New York: Oxford University Press, 1996.

${ }^{11}$ van Velthoven, B., "Empirics of tort", in Faure, M. (Editor), Tort Law and Economics, Vol. 1 Encyclopedia of Law and Economics, 2nd edition. Edward Elgar, Cheltenham, UK, Northampton, MA, USA, 2009.

${ }^{12}$ Sloan, F., and Chepke, L., "The Law and Economics of Public Health", Foundations and Trends in Microeconomics, Vol. 3, No. 5-6, 2007, pp. 331-490. http://dx.doi.org/10.1561/0700000020

${ }^{13}$ Liao, Y.-P., and White, M.J., "No-fault for motor vehicles: An economic analysis", American Law and Economics Review, Vol. 4, No. 2, 2002, pp. 258. http://dx.doi.org/10.1093/aler/4.2.258 
${ }^{14}$ Posner, R., Economic Analysis of Law, 8th edition, Wolters Kluwer, 2011.

${ }^{15}$ Swan, P., "The Economics of Law: Economic Imperialism in Negligence Law, No Fault Insurance, Occupational Licensing and Criminology?", Australian Economic Review, Vol. 17, No. 3, 1984, pp. 92-108. http://dx.doi.org/10.1111/j.1467-8462.1984.tb00460.x

${ }^{16}$ McEwin, I., "No-Fault and Road Accidents: Some Australasian Evidence", International Review of Law and Economics, Vol. 9: 1984, pp. 13-24. http://dx.doi.org/10.1016/0144-8188(89)90003-3

${ }^{17}$ Hause, J., "Fatal Encounters: An Economic Theory of Accidental Injury with Application to New Zealand's No-Fault System", George J. Stigler Center for the Study of the Economy and the State, the University of Chicago, Working Paper Series, No. 116, 1995. 